\title{
Blood Recycling in Gastrointestinal Bleeding: Perspectives and Hopes
}

\author{
Riham Rabie Issa and Ahmad Mohamed Sira* \\ Department of Pediatric Hepatology, Menofiya University, Egypt
}

Submission: June 7, 2019; Published: June 14, 2019

"Corresponding author: Ahmad Mohamed Sira, Department of Pediatric Hepatology, Gastroenterology, and Nutrition, National Liver Institute, Menofiya University, 32511 Shebin El-koom, Menofiya, Egypt

\section{Abstract}

Gastrointestinal bleeding is a common cause of morbidity and mortality in all age brackets. Blood transfusion is one of the principal resuscitative lifesaving actions in this critical condition. However, shortage in banked blood beside other risks of blood transfusion constitutes a significant challenge. The patient own blood recycling has long been introduced in cardiac surgery. Many developments of this innovative technique have been settled since then with its usage in other situations as trauma and vascular surgery. However, its usage in gastrointestinal bleeding was not discussed before. We would like to highlight about the needs and obstacles regarding autotransfusion by blood recycling in these patients.

Keywords: Autotransfusion; Blood recycling; Gastrointestinal bleeding; Mortality; Cross matching; ABO blood group; Donors; Transfusion; Pulmonary cardiac bypass; Blood banks; Blood groups

\section{Text}

\section{What is known and objective}

Gastrointestinal bleeding carries high risk of mortality for both children and adults. One of the most lifesaving interventions in their management is the timely resuscitation with optimum blood transfusion [1]. However, many obstacles still present in spite of the widespread blood banks and advances in stored blood preparation. Shortage in donors relative to the high needs, rare blood groups, transfusion reactions, the blood transfusion risk of infection, incompatible cross matching even for the same $\mathrm{ABO}$ blood group secondary to previous frequent transfusions are some of the transfusion related problems.

So, it is well known that homologous (allogenic) blood transfusion in general is not without a risk [2]. In an effort to reduce these risks some centers were concerned with autologous blood transfusion (autotransfusion) for elective conditions by the banking of the patient's own blood in preparation for surgery. However, this modality will not have a place in those with emergency need as in acute blood loss.

Autotransfusion of the patient lost blood after its recycling; a process called blood salvage (BS), could have a place in emergency blood loss and solve all these transfusion related problems. Autotransfusion through BS has been first introduced in clinical practice in cardiac surgery with pulmonary cardiac bypass, in which the blood lost in the surgical field is processed and retransfused to the patient. This procedure saved the blood resources and introduced safe blood for the patient. Later on, autotransfusion was introduced in orthopedic, trauma, transplant, vascular, and OBGYN surgeries [3].

However, its application was not applied neither discussed in this devastating gastrointestinal bleeding.

\section{Comment}

Autotransfusion through patient lost blood recycling has been introduced in clinical practice 50 years ago, with successful usage in cardiac surgeries. The Cell Saver Elite system provides hospitals with an easy-to-use, reliable way to recover and deliver back a patient's own high-quality blood during medium to high blood loss procedures. In this process, collected blood was re-circulated in the cell saver machine and blood was filtered from fat contents, contaminations, distorted RBCs, and only healthy RBCs were reintroduced to the patient [3].

This technique carried many benefits to the patient. It avoids the risk of unknown and known blood borne infections and the possible transfusion reactions with isotransfusion. Moreover, the quality of autotransfused RBCs are better than the banked ones. Old researches have clearly shown that almost unlimited amounts of blood can be salvaged during surgery and then simply and safely returned to the patient $[4,5]$. 
Moreover, when used appropriately, by adequately trained staff, Intraoperative Cell Salvage (ICS) is a simple, safe and cost-effective method of reducing allogeneic transfusion [6].

It was found that patients whose own red blood cells are recycled and given back to them during heart surgery have healthier blood cells better able to carry oxygen, where it is most needed, compared to those who get transfusions of blood stored in a blood bank [7].

Researchers found that the more units of banked blood a patient received, the more red cell damage they observed. The damage makes the cells less flexible and less able to squeeze through a body's small capillaries and deliver oxygen to tissues. Among patients who received five or more units of red blood cells from a hospital blood bank during the study, the damage persisted for at least three days after surgery [8].

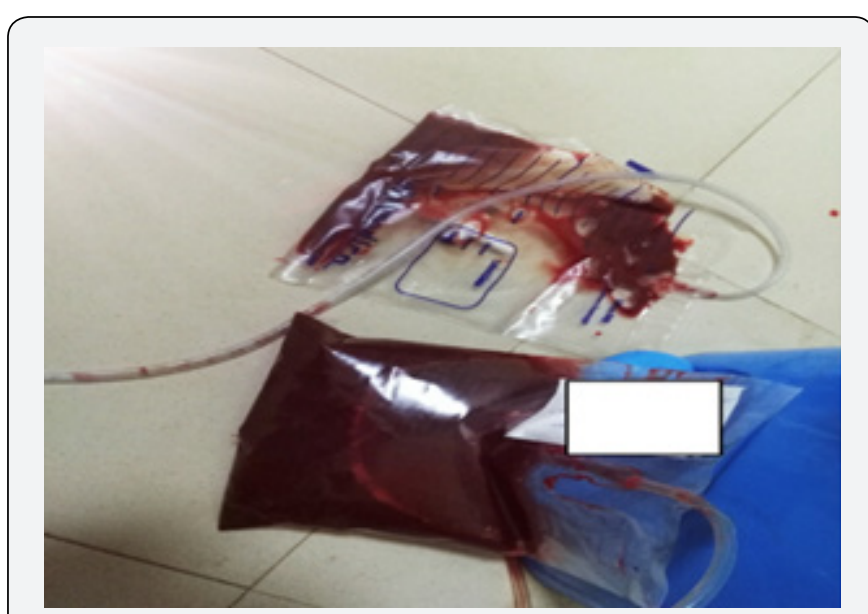

It is an image of one of the many bags of collected blood through the nasogastric tube in an adolescent 14 years old presented with massive upper gastrointestinal hemorrhage due to actively bleeding duodenal ulcer with spurting hemorrhage. He was presenting with hemoglobin of $2 \mathrm{~g} / \mathrm{dl}$. He was transfused 6 bags of banked packed RBCs just to attain a hemoglobin level of 6.9 $\mathrm{g} / \mathrm{dl}$ due to the massive ongoing loss.

Figure 1: Image of collected blood during massive upper gastrointestinal hemorrhage.

In the past, studies have linked transfusions to increased risk of hospital-acquired infections, longer hospital stays and increased risk of death. The fresh blood cells are expected and shown to be of a higher quality than what comes from a blood bank. Moreover, patients feel better about getting their own blood [7].

Usually in GIT bleeding, RBCs transfusions are indicated for those with significant blood loss to achieve a hemoglobin level of around $8 \mathrm{~g} / \mathrm{dl}$ [1]. Sometimes blood loss is massive to the degree that drained blood through the nasogastric tube collects a significant volume of fresh blood in the bag, as if it is a banked blood bag (Figure 1). At which time the rate of bleeding is sometimes massive that couldn't be easily compensated by stored banked blood. This situation could be optimally managed by recycling of the patient own lost blood through the cell saver system.
Theoretically speaking, many obstacles stand against the autotransfusion of the GIT blood loss. Expected obstacles for autotransfusion are the acid media of the stomach, risk of blood digestion when it remains in the stomach for sufficient time, blood clotting, and non-sterilized media with the risk of blood contamination with gastric food contents and infecting organisms. However, most of these obstacles are expected to be higher in those with mild bleeding rate that permits long stay of blood in the stomach with either presentation with melena or hematemesis of coffee brown digested blood. These situations are most probably mild, even with no need for blood transfusion.

However, the speaking about autotransfusion will be considered only in those with massive blood loss at which time much of these expected difficulties will be lessened. When GIT bleeding is massive all gastric contents are emptied early in the first attack with the upcoming blood is devoid of these contents. Moreover, the routine usage of proton pump inhibitor decreases the gastric acidity. We propose that collecting the blood lost during GI bleeding, separating healthy RBCs and reinfusion to the patient using the cell saver system might drastically improve the management outcome and be cost effective.

\section{What is New and Conclusion}

The new is the hope and highlighting for the possibility of the application of the cell saver system on the lost GIT blood due to massive GI hemorrhage and its reinfusion into the patient. In spite obstacles could be viewed much, nothing is impossible as long as all are known and trying to solve point by point.

\section{References}

1. Stanley AJ, Laine L (2019) Management of acute upper gastrointestinal bleeding. BMJ 364: 1536.

2. Koo BN, Kwon MA, Kim SH, Kim JY, Moon YJ, et al. (2019) Korean clinical practice guideline for perioperative red blood cell transfusion from Korean Society of Anesthesiologists. Korean J Anesthesiol 72(2): 91118.

3. Haemonetics (2019). Cell Saver $®$ Elite $®$ Autotransfusion System.

4. Wall W, Heimbecker RO, McKenzie FN, Robert A, Barr R (1976) Intraoperative autotransfusion in major elective vascular operations: a clinical assessment. Surgery 79(1): 82-88.

5. Heimbecker RO (1979) Recycling blood. Surgery, gynecology \& obstetrics 148(2): 243.

6. Murphy GJ, Rogers CS, Lansdowne WB, Channon I, Alwair H, et al. (2005) Safety, efficacy, and cost of intraoperative cell salvage and autotransfusion after off-pump coronary artery bypass surgery: a randomized trial. J Thorac Cardiovasc Surg 130(1): 20-28.

7. Frank S (2014) Recycling a Patient's Lost Blood During Surgery Better than Using Banked Blood.

8. Salaria ON, Barodka VM, Hogue CW, Berkowitz DE, Ness PM, et al. (2014) Impaired red blood cell deformability after transfusion of stored allogeneic blood but not autologous salvaged blood in cardiac surgery patients. Anesth Analg 118(6): 1179-1187. 
This work is licensed under Creative Commons Attribution 4.0 License

DOI: 10.19080/ARGH.2019.13.555859
Your next submission with JuniperPublishers will reach you the below assets

- Quality Editorial service

- Swift Peer Review

- Reprints availability

- E-prints Service

- Manuscript Podcast for convenient understanding

- Global attainment for your research

- Manuscript accessibility in different formats ( Pdf, E-pub, Full Text, audio)

- Unceasing customer service

Track the below URL for one-step submission https://juniperpublishers.com/online-submission.php 